\title{
Military Migrants: Luxembourgers in the Colonial Army of the Dutch East Indies
}

\author{
ULBE BOSMA and THOMAS KOLNBERGER* \\ E-mail: ubo@iisg.nl, thomas.kolnberger@uni.lu
}

\begin{abstract}
Among the roughly 150,000 soldiers sent to the Dutch East Indies between 1815 and 1914, the Luxembourg contingent made up a tiny minority of just 1,075 men. Based upon extensive research into their careers, data on these soldiers provide further clues to understanding what drove Europe's young men to become colonial soldiers. The results of this national case study will be compared with earlier investigations by Bossenbroek and Bosma on recruits for the Dutch colonial army. Similar to the Dutch soldiers, their Luxembourg counterparts had a predominantly urban provenance. However, in contrast to the Dutch, they did not have a strong military background, and it appears that fewer Luxembourgers stayed behind in the Dutch East Indies after their tour of duty. They were more attracted by the payments that the recruiters doled out in advance, particularly at a time of economic crisis, than in a career in the tropics.
\end{abstract}

Keywords: Indonesia, Luxembourg, recruitment, colonial army, life course.

\section{Introduction}

While there has been extensive study of the nineteenth-century transatlantic migration of Europeans, the same is definitely not true with respect to European migration to colonial destinations in Africa and Asia at that time. A number of historians have shown that the latter type of migration was crucial in forging colonial empires, but the works mostly focus on colonial elites. ${ }^{1}$ Little is known about the rank and file apart from the fact that they consisted overwhelmingly of soldiers. These servicemen have been characterised as sharing a "culture of mobility" with other itinerant workers; however, this mobility was exclusively connected to the operating requirements of colonial military policy and not to the role individuals played to satisfy their particular job ambitions or fulfil their desire to accumulate savings.

In the nineteenth century, about six million men from all over Europe left their homes to serve in colonial armies overseas. Between 2 and 4 percent of the young male populations of Great Britain, France, Spain, and Portugal, and between 1.5 and 2 percent of young Dutch men were posted to colonial garrisons. ${ }^{2}$ The "bureaucratic 
intervention state" ${ }^{3}$ also increased the numbers because of security concerns; in particular, the "Great Mutiny" (or Indian Rebellion) of the sepoy regiments in British India in 1856-58 compelled the colonial government in Batavia and The Hague to send more European forces to Southeast Asia from the middle of the century onwards. In addition to the rising numbers of recruits, their prospects of survival increased as health conditions improved. ${ }^{4}$

Well into the nineteenth century, soldiers were the most important migrant category in European colonial empires, including the colonies in temperate climate zones, like South Africa. The overwhelming majority of colonial soldiers sent from Europe to parts of the British, French, Portuguese, and Spanish empires were professionals. In the first half of the nineteenth century especially, many soldiers died from tropical diseases or in battle. Although most of those who survived their often challenging tour of duty in tropical or semi-tropical colonies returned or moved around the empire, there is evidence of a significant proportion of British soldiers staying behind in British India after completing their service, as well as of Spanish soldiers staying on in Cuba. ${ }^{5}$

Systematic research into the social background of European colonial soldiers is scarce, and this also applies to the nineteenth century. The social history of the important mercenary category of Swiss soldiers in that century, for example, is practically unexplored. ${ }^{6}$ We know a little bit more about Irish and Scottish soldiers, who made up more than half of the British colonial garrisons by the mid-nineteenth century; these garrisons were part of the British professional army, except in India, where the East India Company had its own regiments. ${ }^{7}$ According to Spiers, ${ }^{8}$ men were encouraged to enlist because of a desire — or need - for alternative employment; like Marshall, ${ }^{9}$ he emphasises the low social background of the members of the British military. However, the share of unskilled labourers among the recruits of the regular British army, which populated garrisons all over the British Empire, was not overwhelming, although it would rise from about 50 percent in 1860 to more than 61 percent in $1900 .^{10}$

In French colonial history the Foreign Legion, established in 1831, is a well-known phenomenon; less known is that within the French conscript system there were special units made up of men with prison records or of bad repute in civil life, specifically those who had shown the slightest measure of "deviant" behaviour during their regular service. They were called the "corps spéciaux de l'armée française," "dépôts de correction," or "compagnies disciplinaires." Since the colonial troops were drawn from the regular conscript army, their social backgrounds varied. Hardly any of the soldiers assigned to the colonies wanted to stay in the colonies longer than was absolutely necessary. ${ }^{11}$

Available literature on the social composition of the European recruits of the armies stationed in the colonial empires suggests that these soldiers came from the lower societal echelons of continental Europe, simply because most colonial armies were part of the regular armies in which the rank and file came from the lower strata of society. ${ }^{12}$ However, this was not the case with the Dutch colonial army, which tried to attract a specific category of soldiers for whom the prospect of earning a relatively 
large amount of money within a short period was an appealing proposition. These recruits apparently brushed off the dangerous nature of this assignment in the hope of returning with enough savings to start their own business. Bosma has further emphasised enlisting as an alternative route of migration by skilled workers seeking a new existence in a settlers' society after completing their service in the colonial army. To test these assumptions, the only in-depth information we have collected so far relates to the social and geographical backgrounds of Dutch recruits for the colonial army of the Dutch East Indies. ${ }^{13}$

This article provides additional material about the social background and motivations of colonial military based upon a database of the approximately one thousand Luxembourg soldiers enrolled in the Dutch colonial army. An important conclusion is that this group served for a shorter time than recruits from the Netherlands. They did not opt for a full career in the army, unlike the Scottish, for example, who usually stayed in the British army for about twenty years. The Luxembourgers were less inclined to stay in the Dutch East Indies after their service than their Dutch colleagues and did apparently not perceive enlisting in the colonial army as a migration opportunity. ${ }^{14}$ The present article also provides further clues to help understand young European men's motivations for becoming colonial soldiers. The role of professional recruiters acting on behalf of foreign armies deserves specific mention here. ${ }^{15}$

\section{The Dutch Army Overseas}

The Dutch colonial army was a rather multinational crowd. A substantial number of soldiers came from Germany and Belgium, followed by recruits from Switzerland, France, and Luxembourg. The latter had strong links to the Netherlands through a personal union between the king of the Netherlands and the grand duke of Luxembourg, which lasted from 1815 until 1890. Although the more than one thousand Luxembourgers were just a minor element within the Dutch colonial army, for the Grand Duchy itself, this engagement was far from negligible. After all, in the 1870 s, when the army was desperate for new recruits because of its colonial war in Aceh, Luxembourg's population was less than 200,000, and the number of healthy young men who were fit for military service was probably less than 20,000. And yet, during that decade, about 350 men from Luxembourg-1.75 percent of their age cohort - set out for the Netherlands to embark in Harderwijk for the barracks in the Dutch East Indies. ${ }^{16}$ This figure does not even take into account the recruits who joined the French Foreign Legion. Even though it did not have any colonies, Luxembourg provided a greater share of its young men to colonial armies than did the Netherlands, 1.5 percent of whose young men served in its colonial army. ${ }^{17}$ European countries that did not have colonies supplied soldiers to those that did. For most of the century, Luxembourg fit the broader European pattern.

Throughout modern European history, armies have been major employers of professionals and produced important migratory systems. The demand for military 
personnel came not only from states but also from agencies such as the Dutch East India Company (VOC). A Luxembourg mercenary regiment of some 1,110 soldiers had been stationed in Ceylon (present-day Sri Lanka) in 1781 to defend the island together with the Württemberg and the Swiss de Meuron regiments. ${ }^{18}$ Luxembourgers were also among the tens of thousands of experienced soldiers looking for employment in the wake of the demobilisation of armies from the Napoleonic era. In many European countries, all-volunteer and mercenary armies or standing armies of drafted recruits continued to function well into the nineteenth century. ${ }^{19}$ Swiss professional soldiers served in the Dutch standing army until 1829, for example. Throughout the nineteenth century, the French and Dutch colonial armies, in particular, were keen to enlist young men from countries that did not have colonies themselves. ${ }^{20}$

The archival records of the Dutch colonial army in the Dutch National Archives as well as the Archives nationales de Luxembourg, provide us with unique insight into the motivations and social backgrounds of the Luxembourg recruits. These data also lend themselves to a comparison with data that Bosma has gathered on Dutch colonial recruits and may offer us some stepping stones towards a fuller understanding of the reasons why young men enlisted in colonial armies. As was true of recruits from the Netherlands, Luxembourg's colonial soldiers often came from an urban, albeit in the case of the Grand Duchy a small-town, background. They were from a poor, but not the poorest, strata of society. ${ }^{21}$ Rapid population growth, which reached 1.5 percent shortly after the Napoleonic era, forced many Luxembourgers to look for employment elsewhere. Remarkably, in contrast with Bosma's conclusions about Dutch and other European colonial soldiers, the average Luxembourger who enrolled in the Dutch colonial army did not consider his military service a point of entry to a colonial career; instead, they were "life-cycle migrants," attracted by the prospect of eventually returning to Europe with some savings. ${ }^{22}$ Although some made careers and rose in the colony's civilian life or military, they may not have had this goal ahead of time.

\section{Dissolving Ties with the Netherlands and Germany}

The political status of Luxembourg as a supplier of soldiers to the Dutch colonial army changed entirely during the nineteenth century. The Grand Duchy transformed from the rather hybrid position of being part of the Kingdom of the Netherlands and the German Confederation to a neutral independent state. Obviously, this transformation also altered the channels through which the country's citizens joined the Dutch colonial army.

After Napoleon's fall, the Congress of Vienna recreated the (United) Kingdom of the Netherlands with the historical Low Countries as a palimpsest. Luxembourg's borders were rearranged, and the territory was downsized from the former Duchy of the Austrian Netherlands (until 1795) and the French department (Département des Forêts, 1795-1814/15), but its formal political status was elevated to that of grand duchy to give its new head of state a royal rank in the German Confederation. King 


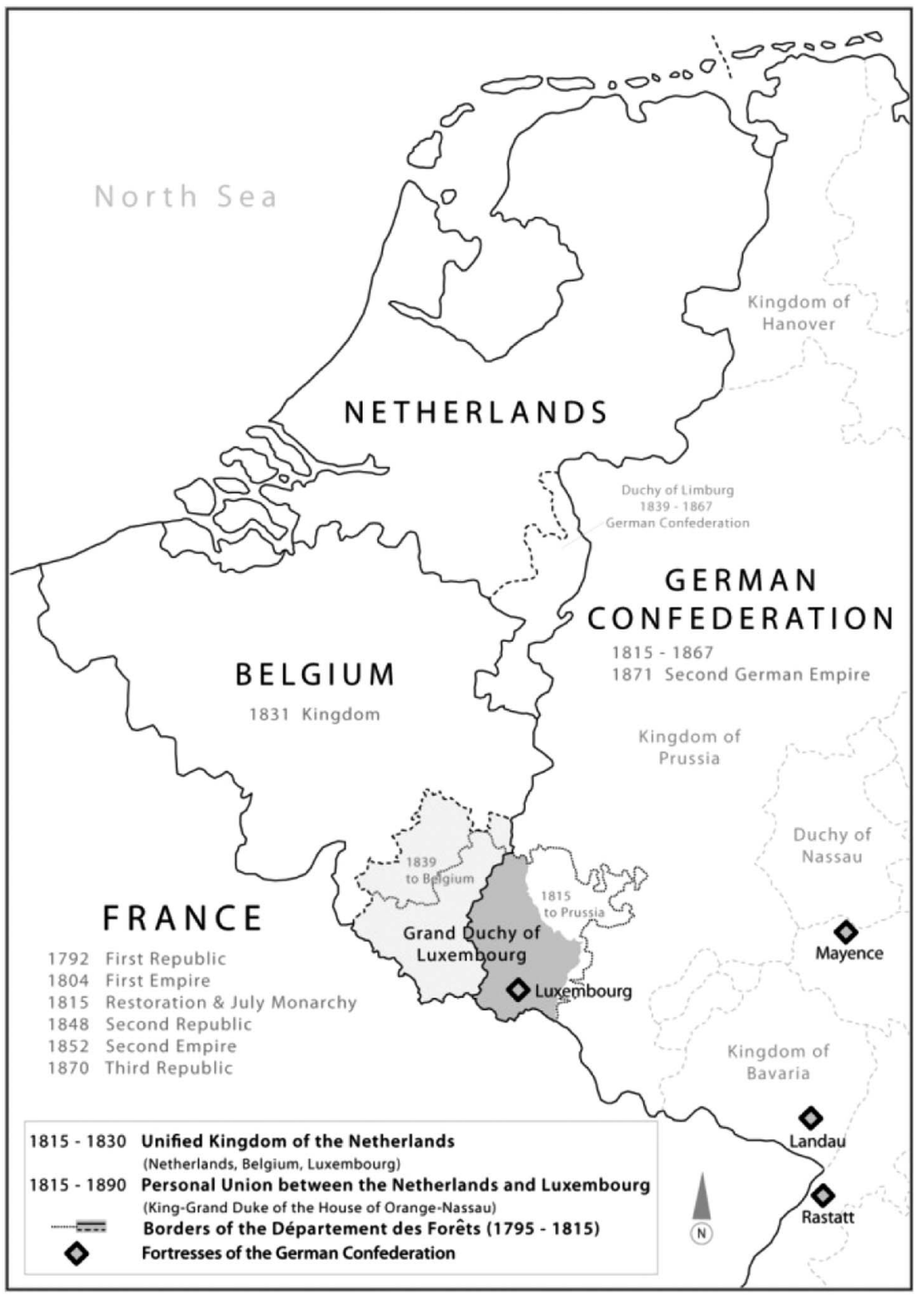

Figure 1. Territorial changes of Luxembourg during the nineteenth century. (Map designed by T. Kolnberger) 
William I of the Netherlands also became grand duke of Luxembourg to represent the territory within the Deutscher Bund (German Confederation, 1815-67). ${ }^{23}$ Each member state of this loose confederacy, created as the centrepiece of a European framework of peace, order, and conservative government dominated by Prussian-Austrian antagonism, had to contribute troops to a federal army (Bundeskontingent) ${ }^{24}$

Up until the Belgian Revolution of 1830, Dutch officers commandeered the Luxembourg militia contingent, while the important fortress of Luxembourg - one of five Bundesfestungen against France- - had a Prussian garrison. ${ }^{25}$ As a result of the secession of the southern provinces of the Netherlands in 1830-31/39, the Grand Duchy lost its north-western, predominantly francophone territories to the newly founded Kingdom of Belgium (now the Belgian province of Luxembourg). The shrinking of the territory also diminished the recruitment pool for the Dutch colonial army, a point to which we will return. Meanwhile, the king's men in the administration and military left Luxembourg or were naturalised, while the grand duke remained in place as a Dutch head of state of a German principality, albeit as a mostly absent ruler, tax receiver, and addressee of petitions or mercy pleas. ${ }^{26}$ The Grand Duchy of Luxembourg became a de facto independent state. The country gained full "independence" in 1890 after the male line of the House of Orange-Nassau died out and - in line with the succession rules of the House of Nassau (Nassause Erfvereniging) - the throne passed to Adolph of Nassau-Weilburg of the new ruling branch. ${ }^{27}$

In retrospect, the dissolution of the personal union with the Kingdom of the Netherlands was the final step in a long evolution towards Luxembourg becoming a fully independent nation state. Luxembourg already had its own constitution by 1841 , the foundation stone of a national diocese with its "own" first Catholic bishop (then apostolic vicar) the same year, the creation of a rabbinate, and entry into the Deutscher Zollverein (German customs union, 1834-1919) in 1842. ${ }^{28}$ The Grand Duchy's membership in this strongly integrative economic union was the only one that was not sealed politically in 1871, when Luxembourg did not become part of the Second German Empire (1871-1918). ${ }^{29}$ The reason for its continued existence as a small principality was that the German Confederation was dissolved after the 1866 Austro-Prussian War, and Luxembourg was declared neutral in perpetuity, guaranteed by the Europe's Great Powers in the Treaty of London of 1867. The fact that France and Prussia denied each other possession of Luxembourg preserved its independence under the neutral crown of a Dutch king.

\section{Numbers and Percentages}

Based on documentation from the Luxembourg archives, Yvan Staus counts 1,129 persons who enlisted in the Netherlands' colonial army in the nineteenth century. A cross-check with Dutch military sources produces a smaller number, as some people might have professed a willingness to join the Dutch army but never did - for various reasons, including that they did not pass the medical examination. According to our data, based upon a variety of sources, the great majority of the 1,075 
Luxembourgers were recruited by the Dutch colonial army between 1815 and $1909 .{ }^{30}$ However, the size of the sample would probably be significantly higher if one were to count soldiers who were - due to the political vicissitudes of Luxembourg's borders - "unsure" about their nationality and did not register themselves as Luxembourgers yet appear as Luxembourg citizens in other sources. ${ }^{31}$ Luxembourgers were admittedly marginally represented among the around 154,000 colonial soldiers and noncommissioned officers who served in the Dutch East Indies between 1815 and 1909. Excluding commissioned officers, 60 percent were Dutch, followed by Belgians and Germans (14 percent each), French and Swiss (4 percent each). The accumulated share of Luxembourgers is only 0.61 percent. $^{32}$ However, the 600 Swiss soldiers leaving for the Dutch East Indies between 1873 and 1879 represent a much smaller share of the Swiss population at that time-which was 2.5 million-than the Luxembourgers. $^{33}$

The curve in figure 2 shows a peak in the 1820s and a significant drop in the number of enlisted men after the 1840s. The explanation for this volatility lies both in the Dutch East Indies and in Europe. After the Napoleonic era, the British returned rule over the East Indies to the Netherlands. The formation of a new-style colonial army on the archipelago, the KNIL (Koninklijke Nederlandsch-Indische Leger, or Royal Dutch-East-Indies Army), attracted a rising number of Luxembourgers as soldiers, who were desperately needed during the Java War (1825-30) and the Padri War (1821-35). The events of the Belgian Revolution and secession represent the European factor of the explanation because military service for Luxembourgers was suspended in the grand duchy between 1830 and 1839/40.

The peak in the 1870 s can be explained by the increasing demand for recruits during the first phase of the Aceh War (1873-1914), which led to intensive recruiting

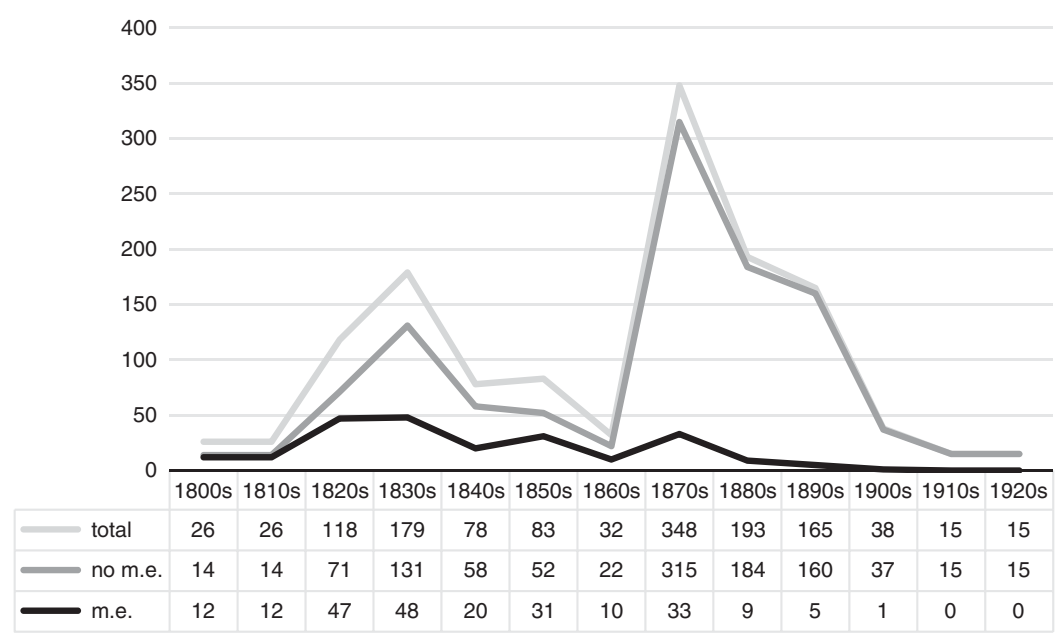

Figure 2. Number of Luxembourgers enlisted in the KNIL between 1800 and 1920. Source: See Appendix 1.

m.e. $=$ soldiers with military experience prior to their KNIL engagement 
efforts for the KNIL. Military recruitment agents also visited Luxembourg in these years, and they were particularly active in urban areas. ${ }^{34}$ In addition, the catchment area for recruiting had changed: While French names had dominated the enrolment list of Luxembourgers in the colonial army before the collapse of the old unified Kingdom of the Netherlands, the now-predominantly Germanic family names point to the loss of the Grand Duchy's francophone west (and immigration from Germany) ${ }^{35}$ After the Great War of 1914-18, there were virtually no Luxembourgish servicemen in the Dutch East Indies, and the total number of Luxembourgers in 1930 was forty-six, of whom twenty-two were born in the colony. ${ }^{36}$

\section{Luxembourgers and Military Careers}

The recruitment pattern of Luxembourgers into the KNIL brings together the European and Indonesian theatres of war. The French Revolution caused a significant militarisation of Europe: Twenty years of military conflict trained more young males for military service than ever before. As in many other professions, the skills learned in one army could be transferred to another. Some of the Luxembourg military men had already served in a number of armies before they left for the Dutch East Indies.

Franz Böfinger (or François Boefinger), for example, who was born in Luxembourg City in 1790, became an Austrian cadet in 1805. He later changed his allegiance, perhaps the same year, after the crushing defeat suffered by the Austrian army and their Russian allies at Austerlitz, and eventually he climbed to the rank of lieutenant in the French imperial army in 1811. Two years later, he enlisted in the Prussian army, where he was promoted from second to first lieutenant. Like many officers who found themselves unemployed after Napoleon had disappeared from the scene, he sought employment outside of Europe - in this case, in the Dutch East Indies. In 1818, he entered the army of the Netherlands and was promoted to captain before being transferred to the army in the Dutch East Indies. ${ }^{37}$

While political borders across Europe shifted, creating new socio-economic situations and challenging personal loyalties for countless individuals, the wider historical area of the southernmost Low Countries remained a stable reservoir for military recruitment. Geographically and in terms of military workforce recruitment area, the Luxembourgers were part of the much wider "North West" of Germany (including the Rhineland). ${ }^{38}$

Although some of the recruits for colonial armies never had any military experience, particularly in the early part of the nineteenth century, a substantial minority could still be considered part of the professional military.

However, the military background of the Luxembourg recruits was less pronounced than that of their Dutch counterparts, which can be explained in part by the fact that their presence was the result of recruitment efforts rather than the conscious choice of a military career. About 75 percent of all Dutch colonial soldiers had already served in the metropolitan Netherlands' army, either as conscripts or as professionals, which explains why the average age of the soldiers leaving for the 
first time to the Dutch East Indies was twenty-five. ${ }^{39}$ During the nineteenth century, an average of only 20.3 percent (218) of the Luxembourg recruits had had military experience prior to their enrolment in Dutch colonial army service, compared with 40 percent of the German volunteers. ${ }^{40}$ In the first half of the century (until the 1850s), 33.3 percent were "veterans." Between the 1860 s and the First World War, this rate dropped to 7.20 percent of re-enlistment. There were some military institutions in Luxembourg that produced trained soldiers, but these were fairly modest. By far the largest contingents of trained military consisted of Luxembourgers who had served in the Netherlands' Army or the Corps de Chasseurs Luxembourgeois. A small group of thirty-three seemingly opted for a military career, as they had already had two or three military employers before joining the KNIL.

More than half of the 218 trained soldiers (132) had been enlisted in the Netherlands' military units. Luxembourgers were subject to the king of the Netherlands, and there were no legal barriers to their recruitment until the 1830s-40s. Of course, soldiers who had already been enlisted in the army of the Netherlands would have had a much greater chance of ending up in the Dutch East Indies than the average young Luxembourger.

The second-largest group consisted of the different army institutions of the Grand Duchy of Luxembourg itself. Between 1816 and 1856, about a quarter of the German Confederation's troops in the Grand Duchy comprised some 3,000 Luxemburgish militiamen (though not serving in the Confederate Fortress of Luxembourg, these troops were stationed in separate military barracks in the country). ${ }^{44}$ Furthermore, the militia (1817-41) and the Federal Contingent of Luxembourg (1841-67), the latter being set up after the Belgian Revolution, relied on a socially biased

Table 1. Previous military experiences of Luxembourgers in the KNIL

\begin{tabular}{lr}
\hline \hline Netherlands' Army & 110 \\
Dutch West Indian Army (West Indisch Leger) & 3 \\
Cleerens Rifles Corps (Korps Jagers van Cleerens, 1831-39) & 19 \\
Luxembourg Rifles (Corps des Chasseurs Luxembourgeois) & 42 \\
Gendarmes and Volunteer Corps (Corps des Gendarmes et Volontaires) & 4 \\
Federal Contingent (Bundeskontingent of Luxembourg) & 6 \\
France (since the First Republic) & 19 \\
French Foreign Legion & 16 \\
Belgian Army & 19 \\
Prussian Army & 9 \\
Austrian Army & 2 \\
Papal Zouaves (1860-70) & 2 \\
British-German and British-Swiss Legion (1855-56) & 43 \\
Total (military service) & 9 \\
Total (individual soldiers) & $\mathbf{2 6 0}$ \\
\hline
\end{tabular}

Source: Appendix 1. 
conscription system. After the dissolution of the German Confederation and the withdrawal of the Prussian garrison in 1867, Luxembourg established a new military organisation, the Corps des Chasseurs Luxembourgeois (the Luxembourg Rifles, a light infantry battalion). This militia-based system, the last of its kind in the country, was disbanded in 1881 and replaced with a paramilitary volunteer force (Corps des Gendarmes et Volontaires) until 1940. Few from this latter corps were enlisted in the Dutch colonial army, which is not surprising since this corps of volunteers was in fact a civil staff reserve unit and recruitment pool for further uniformed state jobs, for example in customs, the mail, or railway.

In particular, military service in the Dutch home army was an important springboard for further enrolment in the KNIL. Not until 1841, two years after the Treaty of London recognised and guaranteed the independence and neutrality of Belgium and the independence of Luxembourg, did a mixed commission of Dutch and Luxembourgish military and state officials visit the parishes of the Grand Duchy to recruit volunteers. These potential soldiers, however, still had to serve their time in the local militia before they could enlist in the Dutch home force (landmacht) or the colonial army. ${ }^{45}$ Obviously, this restriction was implemented only briefly, and the law became a dead letter, as the recruiting figures of Luxembourgish subjects rose sharply in the 1860 s and 1870 s.

After the secession of Belgium from the Kingdom of the Netherlands and the consolidation of a more independent Luxembourgish state, the officials and government of the Grand Duchy did not prevent their subjects from looking for military employment abroad. In the case of the Netherlands, they more or less pursued a policy of laissez-faire with regard to army recruitment, yet they played a more proactive role regarding the support of veterans' or surviving dependants' legal and pension claims. A new phase in the recruitment for the Dutch colonial army came with the end of German Confederation after the Austro-Prussian War of 1866 also terminated the Confederation's "Allgemeine Cartell-Convention"-a general framework regulating the treatment of deserters and military recruitment by agents (Werberwesen). From now on, licensed private recruiters of Luxembourgish nationality took over and arranged not only "civil" emigration overseas (Auswanderungs $=$ Agenten $)$ but also acted as agents for military mercenaries on behalf of foreign colonial powers, including the Netherlands. ${ }^{46}$

While the recruits' military background declined over the course of the nineteenth century, a development in which the slackening of ties with the Netherlands played a major role, it appears that the colonial soldiers' strong urban representation remained stable. Staus estimates that about 50 percent of all Luxembourg recruits in the Dutch colonial army were born in an urban environment, mostly the capital, even though it accounted for just 10 to 15 percent of the total population of Luxembourg. ${ }^{47}$ The capital was thus heavily overrepresented. Moreover, with the exception of the late 1880s, when both enlistment in the Dutch colonial army and migration to the United States reached a peak, military migration followed its own rhythm, distinct from transatlantic migration. ${ }^{48}$ The fact that enlistment increased between five and ten 
times during the Java and Padri Wars in the early nineteenth century and in the Aceh War (1873-1914) strongly suggests that the Dutch colonial army promoted recruitment in Luxembourg. Its agents, who received a bounty for each individual they enlisted, also appear to have employed questionable methods, as records show that the Luxembourg authorities tried to suppress emigration agents' deceitful practices. ${ }^{49}$

The recruiters came at the right moment, as 1873 also marked the beginning of the "long depression" that would continue until 1879 (or the "great depression" until 1896), which was most severe in Western Europe and North America. This recession slowed economic growth and industrial expansion. While the standard of living in Luxembourg generally improved during this period, an individual crisis like a 15 percent decline in cast-iron production in the Zollverein brought sudden misery to local communities. Under such circumstances, the Dutch colonial army recruiters' offer of a premium of 300 guilders for a six-year contract and 200 for a four-year contract at a time when a journeyman earned 300 guilders per year was very tempting. ${ }^{50}$ Probably more than anything else, this explains why the number of Luxembourg recruits soared during the Aceh War. In previous decades, only a handful of young men enlisted, many of them friends or relatives of each other. As Luxembourg is a small country, word-of-mouth advertising was probably the most important factor. Family networks did play a role in the decision to enlist in the Dutch colonial army. To date, we have found thirty soldiers who had relatives in the army, a figure that will rise when more genealogical research is carried out. Wanderlust and itchy feet for exotic countries "automatically" pointed many young men towards the Dutch East Indies, and many reports and serialised novels were printed in the local newspapers during the time in review. The propensity of Luxembourg soldiers to return home to their industrialising country shows analogies with the "Celtic warrior nations": "Scots joined the army from their country's rapidly developing urbanindustrial heartland and eventually returned to there. By contrast, Ireland's overpopulated agricultural economy offered fewer opportunities to Irish veterans."

\section{Evidence for a Luxembourgish "Life-Cycle Soldier"?}

In the early nineteenth century, death rates were extremely high among colonial soldiers. Until the 1840s, only 20 percent survived deployment in the Dutch East Indies. ${ }^{52}$ For Luxembourgers, too, the early decades $(1810 \mathrm{~s}-30 \mathrm{~s})$ had the highest mortality rate (60 percent of the disembarked soldiers). The rate declined significantly in the 1870 s- 90 s to under one-third. ${ }^{53}$ But after the improvement of health care in the colonial army, including measures such as boiling drinking water and the application of prophylactic quinine, the chances of survival improved drastically. In the second half of the nineteenth century, enlisting in the Dutch colonial army was a way for many young Dutch to find employment. Moreover, in the 1860s, the colonial government relaxed the regulations under which Europeans could obtain a residence permit. In these years, migration to the Dutch East Indies (and to Algeria) became an alternative to moving to North America. The advantage of enlisting in the colonial army was that the state paid your fare. 
With regard to Dutch recruits, Bosma and Mandemakers have argued that, contrary to general opinion, these men were not the most socially deprived, if only because many of these would not have passed their medical examination because they were not tall enough as a result of nutritional deficiencies, or they would have been barred from service for not having a clean criminal record. ${ }^{54}$ Like their Dutch counterparts, the Luxembourg soldiers did not belong to the economically weakest strata of society but rather to the lower-middle classes. Staus observes that the literacy rate of Luxembourgers in the Dutch East Indies colonial army was relatively high, but this may also be because literacy in Luxembourg was generally high compared with the country's European neighbours. After the Belgian Revolution, the new administration of the Grand Duchy advanced and regulated the primary education of the country: The reform of 1843 changed the inadequate state of primary school matters, that is, the small number of schools and the underfunding of teaching staff that were taken over from the Dutch-Luxembourgish government. The rate of literacy rose significantly in these decades, reaching 81.3 percent in 1856 and 90.3 in $1880 .{ }^{55}$ By the mid-nineteenth century, the literacy rate among the militiamen was higher than in neighbouring France, Belgium, or Prussia. ${ }^{56}$

Fiscal-military states like the old Dutch Republic or Britain had a high demand for mercenaries, and their voracious appetite meant they accepted even "the scum of every county, the refuse of mankind." 57 This disparaging notion is not applicable to the nineteenth century, however, as Bosma and Mandemakers show in their study based upon the historical sample of the Netherlands. Such a study is not available for Luxembourg, but the face-to-face-society of this small state ${ }^{58}$ facilitated the assembling of data for a good portion of Luxembourgers who served as volunteers in the Dutch East Indies. Pater Martin Blum, who made a compilation of soldiers' and veterans' short biographies (together with the former non-commissioned KNIL officer Johann Peter Troes as his co-author), was a well-known local historian and public figure who could rely on a countrywide network of informants. In his list of veterans, he never misses an opportunity to spice up the sober enrolment statistics with comments about the veterans' good or bad civil conduct. They were, all in all, "normal" people with no particularly desperate underclass stigma. These men were mostly "normal" because they were looking for a job as military migrants on a regularised military labour market. ${ }^{59}$

Born in 1834, the Luxembourger August Nikolaus Joseph Kohl, for instance, served in the Dutch colonial army from 1859 to 1865 . Describing himself as a gifted schoolboy who would have preferred to study further, he explains in his memoirs that his mother was a poor widow and could not afford to pay for his studies. He had to learn the trade of 'ivory turning' (antler, cowhorn, mother of pearl) and worked for four years at a manufacturing plant in Paris. He lost his job when his employer went bankrupt, and he was unable to find a job in Belgium or Luxembourg. In a rather desperate state of mind he decided to take a boat to Maastricht, where he was recruited into the colonial army. ${ }^{60}$ Another example is Michael-Gustav Bück, born in 1849, who joined the Dutch colonial army at the rather advanced age of thirty-one. 
He had already trained as a typographer, his father's trade in Luxembourg. Bück enjoyed a privileged background and could attend the Athenäum/Athénéethe capital's only secondary school at the time. For him, enlisting in the colonial army in 1880 was a way to find a job. After three years in the army, he became a typographer at the colonial government's print office, where he worked another six years before returning to Luxembourg.

Peter Mœs from Luxembourg City was a plasterer on Grand Tour (journeyman years) through Germany, France, and Belgium, before he decided to enlist in the Dutch colonial army. He was twenty-five when he arrived in the Dutch East Indies in 1878, where he was assigned to the engineers' corps (Geniebataillion). After a work-related accident in 1881, he returned to Luxembourg before the end of his contract. After four years in the Dutch East Indies and with the help of his pension, he established his own craftsman's business and married. ${ }^{61}$

However, while the Dutch East Indies offered an increasing number of opportunities for ambitious young men without financial means, employment opportunities in Luxembourg also increased. First, Luxembourg's industrialisation (and the modernisation of the farming and agrarian economy) gained momentum. As a structural part of the Saarland-Lorraine industrial belt (after 1870), the south of Luxembourg (Terres Rouges and the Minette) integrated with Imperial Germany by means of the customs union (Deutscher Zollverein) in 1842 and, dominated by German-Luxembourgish capital, became the Zollverein's second-largest industrial area after the Ruhrgebiet. Owing to this industrial surge, emigration rates declined, especially in the 1880s-90s, when job opportunities were on the rise. Subsequently, skilled and later unskilled workers could pick their jobs in the last quarter of the nineteenth century. Therefore, Luxembourg changed its work migration pattern to become a labour-importing country; in particular, German (from 3,497 in 1875 to 21,762 in 1910) and Italian industrial blue-collar workers (from 71 to 10,138 in the same period) settled in the Grand Duchy. In total, the share of immigrant workers increased from 3 to 18 percent before the First World War. ${ }^{62}$

Second, from the $1860 \mathrm{~s}$, the grand duchy experienced a significant drop in poverty: ${ }^{63}$ In $1847,12.3$ percent of the 184,099 Luxembourgers were regarded as needy; by 1868 , this rate had dropped to 3.2 percent of an expanding population of 203,664. ${ }^{64}$ Finally, alternative destinations for labour migration emerged-France and its booming capital, Paris, in particular, attracted many Luxembourgers. After the Franco-Prussian War of 1870-71, Paris replaced many of its German domestic servants with Luxembourgish ones (many of whom had basic instruction in French). The decades leading up to the First World War were also the heyday of female work migration and life cycles of a new group: young rural females from the underclass. The French population census of 1891 counted 31,248 Luxembourgers in France, or 14 percent of the total population of the Grand Duchy; around 27,000 resided in Paris and the Seine department in 1883 . The male and female components of this emigration were quite balanced. ${ }^{65}$

Meanwhile, Luxembourgers' career opportunities in the Dutch colonial army were limited. Although almost one-third of them were promoted in the colonial army, 
a ratio equivalent to that of the Dutch, their chances of becoming officers were slim. ${ }^{66}$ Rank-and-file promotions to officer happened thirteen times, including to Johann Oberweis, who enrolled in the Dutch colonial army in 1887 and rose swiftly in the ranks. Originally, he was a teacher in Luxembourg and-according to Troes and Blum - longed for a change of scenery. During his second tour of duty overseas, he was promoted to adjutant-quartermaster (a non-commissioned officer focused on logistics) ${ }^{67}$ of the army service corps in 1901. He is one of two Luxembourgers with a fourth service period, ${ }^{68}$ which meant he could increase his military pension continually, from 300 to 666 and eventually 800 francs. He remained a civilian and signed up for a managing position (as stevedore) of a dock company in Batavia. He died from malaria in Weltevreden, leaving behind a widow and four young children. ${ }^{69}$

At just twenty-six, the number of Luxembourg officers represented a much lower share than was the case with the Dutch, which is quite understandable since in principle the Dutch military academy only accepted cadets with Dutch nationality or whose kin had served in the Dutch East Indies. Only during the build-up of the colonial army after the Napoleonic Wars did non-commissioned officers rise to the rank of officer during their time of service. This happened, for example, to FranzKarl Hartmann and Ludwig-Joseph Zelle. ${ }^{70}$ In addition, officers were hired who had already served the Napoleonic, Prussian, Dutch, or other armies. One officer reached the rank of major and another of colonel. Another officer eventually found employment as the commander of the pajurits (dragoon guards) of the sultan of Yogyakarta. ${ }^{71}$ Bosma calculated that, out of the Dutch soldiers and officers recruited in the final decades of the nineteenth century, about 30 percent stayed who had survived their military service and did not return to the recruitment depot in Harderwijk, where all colonial soldiers who returned to Europe were demobilised. In all likelihood, they stayed in the Dutch East Indies. ${ }^{72}$ Comparable figures for Luxembourg soldiers demobilised in Harderwijk do not exist. However, we have an idea of the percentage of native Luxembourgers who did not return to Luxembourg after their time in the Dutch East Indies.

According to the official population registration of all those enlisted between 1890 and 1910, about 20 percent did not return to Luxembourg but instead stayed on, a figure that was lower only in comparison with earlier cohorts. Moreover, these veterans might not have remained in the Dutch East Indies but moved to the Netherlands or Germany. ${ }^{73}$ In the nineteenth century, young men saw enlisting in the army as part of their life cycle: ${ }^{74}$ serving in the Dutch East Indies for a relatively short period before returning home to start their own families, establish a business, or look for permanent work. The option was brought to their attention by commercial recruiters who offered them an advance amounting to a year's wage as a workman. The recruits during the second half of this period in particular qualify for the label of "life-cycle soldier." The average time of service for the Luxembourgish sample is seven years, two fewer than the overall average. During the Aceh War (1873-1904), especially, only one-third of the recruits signed on for a second tour of duty. ${ }^{75}$ The 
Table 2. Johann Peter Troes, "Die Luxemburger in der niederländisch-indischen Kolonialarmee von 1825 in 1913."

\begin{tabular}{|c|c|c|c|c|c|c|}
\hline & \multirow[b]{2}{*}{ Total (1) } & \multirow[b]{2}{*}{ Stayed (2) } & \multicolumn{3}{|c|}{ Left (3) } & \multirow[b]{2}{*}{ Contract (4) } \\
\hline & & & Subtotal & Regular (a) & Irregular (b) & \\
\hline \multirow[t]{2}{*}{$1850-70$} & 68 & 27 & 41 & 21 & 20 & 10 \\
\hline & $30.9 \%$ & $39.7 \%$ & $60.3 \%$ & $51.2 \%$ & $48.8 \%$ & $50.0 \%$ \\
\hline \multirow[t]{2}{*}{$1870-90$} & 301 & 106 & 195 & 140 & 55 & 9 \\
\hline & $46.5 \%$ & $35.2 \%$ & $64.8 \%$ & $71.8 \%$ & $28.2 \%$ & $8.3 \%$ \\
\hline \multirow[t]{2}{*}{ 1890-1910 } & 332 & 135 & 197 & 109 & 88 & 5 \\
\hline & $32.8 \%$ & $40.7 \%$ & $59.3 \%$ & $55.3 \%$ & $44.7 \%$ & $5.7 \%$ \\
\hline
\end{tabular}

declining ambition to reengage after the first contract is definitely related to the decreasing share of Luxembourg colonial soldiers with a military background (see figure above, 'Contract' (4)). Having no relationship with either military work or the Southeast Asian archipelago, these soldiers overwhelmingly ended up in the Dutch East Indies thanks to the efforts of commercial recruiters.

Military contracts of individual soldiers started in the particular decades (overlaps not accounted for).

(1) Total number of soldiers. The quota below refers to soldiers only serving a one-time contract with regular end (e.g. $30.9 \%, n=68$ )

(2) Soldiers staying on in the Dutch East Indies (largely for a second term only). Quota of total number of soldiers of that period.

(3) Soldiers leaving the army after or before ending their first contract with the KNIL (subtotal: number and percentage compared with stayers) with

(a) regular end and,

(b) irregular ones, the latter mostly because of death or health issues.

(4) Soldiers with military service records prior to their engagement in the KNIL (indicative of a tendency to extend their contract in the case of (b), expressed by the quota, e.g. $50.0 \%$ of $n=20$ ).

Moreover, it seems that those with skills were more likely to stay for a longer period of time in the Dutch East Indies, as is suggested by the list established by Troes (and Blum) and that is presented above. It confirms Staus's view that "many soldiers seem to have been craftsmen, workers, rural or urban day-labourers."76 Most Luxembourgers apparently had more difficulty in finding a place in the Dutch East Indies' colonial society or never had the intention to stay on. After all, the Dutch East Indies were not known as a destination for family or settler migration. Those who sought a future 
abroad on a permanent basis went to the United States or to Canada. They travelled in groups from the countryside; sometimes entire villages left, which is a pattern highly comparable to the Netherlands. These settler migrants from Luxembourg tended to settle in certain areas of the Midwest and the Great Lakes region. ${ }^{77}$

Civil migration of Luxembourgers to the tropics, like the Brasilienfahrer, was ill-fated ${ }^{78}$ and military migrants could only achieve a modest career in the army or jobs in the society of the Dutch East Indies. Once they had reached the rank of sergeant (although this was only within reach for a minority of the soldiers), their prospects of finding a place in civil society increased, as they could acquire their own home and could afford to maintain an Indonesian female partner. Heinrich Schliep, for example, became a KNIL soldier in 1854 at the age of twenty. He rose quickly to the rank of sergeant-major (1860) and was transferred to the colonial civil service (topographical unit, cadastre, and teacher in the Gymnasium Willem III in Salemba, near Batavia). With his skills as a draughtsman, he easily found civil employment in the Dutch East Indies. He became a traveller and author (using the pseudonym Henri Schliep von Salemba) thanks to his military and civil pension after twenty-three years of duty in the Dutch East Indies. ${ }^{79}$ Another example was Eugen Müller, who was born in 1881 and served in the Dutch colonial army from 1900 until 1906. He stayed in the colony and was hired as chief storekeeper of the Dutch East Indies railway (Staatsspoorwegen) in Semarang after his discharge as a sergeant in 1906 following only one term in service. ${ }^{80}$ But, again, the careers of Schliep and Müller were exceptional.

\section{Conclusion}

The professional background of the Luxembourger soldiers in the Dutch colonial army and the recruitment practices were subject to major transformations over the course of the nineteenth century. The most important changes resulted from the redrafting of Luxembourg's political status. In the period 1815-30, Luxembourgers were technically subjects of the Dutch crown, although without Dutch citizenship. They were free to enlist in the colonial army and many veterans of the Napoleonic Wars did. From 1830 onwards, the number of Luxembourger soldiers in the Dutch colonial army dwindled, because the supply of military veterans dried up. The end of the German Confederation in 1867, and the formalisation of Luxembourg as a neutral state, opened the door for commercial recruiters acting on behalf of the Dutch colonial army. The number of Luxembourg recruits drastically increased in the 1870s, and while still overwhelmingly urban, fewer had a military background than in the 1815-30 period. However, in contrast to Dutch soldiers, most young men who were enlisted through recruiting agents or signed up on their own initiative were less interested in making a career in the tropics than in the immediate financial benefits, which would help them to find their place in their home society after their return. Although some Luxembourgers did find employment and sometimes even made a career in the colonial civil society by the end of the nineteenth and early twentieth centuries, they mainly came from the minority of the veterans who had acquired skills that were in demand. 


\section{Bibliography}

Abbaye de Neumünster (Centre Culturel de Rencontre). Präsenz, Wirken und Integration von Deutschen in Luxemburg - vom Wiener Kongress bis zum Ersten Weltkrieg (1815-1914). Catalogue of the exhibition edited by Helma Werner. Trier: Ensch, 2013.

Amersfoort, Herman. "The Dutch Army in Transition: From All-Volunteer to Cadre-Militia Army, 1795-1830." In Fighting for a Living. A Comparative History of Military Labour 15002000, edited by Erik-Jan Zürcher, 447-478. Amsterdam: Amsterdam University Press, 2013.

- Koning en kanton. De Nederlandse staat en het einde van de Zwitserse krijgsdienst hier te lande 1814-1829. Den Haag: Sectie Militaire Geschiedenis Landmachtstaf, 1988.

Anciaux, Léon. La participation des Belges à l'œuvre colonial des Hollandaise aux Indes orientales. Bruxelles: Académie royale des Sciences sociales, 1955.

Angelow, Jürgen. Der Deutsche Bund 1815-1866. Darmstadt: WBG, 2003.

—. Von Wien nach Königgrätz-Sicherheitspolitik des Deutschen Bundes im europäischen Gleichgewicht 1815-1866. München: Oldenbourg, 1996.

Arnold, D. "White Colonization and Labour in Nineteenth-Century India." Journal of Imperial and Commonwealth History 11:2 (1982-83): 133-158.

Bayley, Charles C. Mercenaries for the Crimea: The Swiss, German and Italian Legions in British Service, 1854-1856. Montreal: McGill-Queen's University Press, 1977.

Bayly, Christopher A. "'Archaic' and 'Modern' Globalization in the Eurasia and African Arena, ca. 1750-1850." In Globalization in World History, edited by A. G. Hopkins, 45-72. New York: W.W. Norton, 2002.

Beelen, Liesbeth and Geert de Kinkelder. Soldaten Overzee-Aanwijzingen voor het doen van onderzoek naar officieren en personeel van het Koninklijk NederlandschIndisch Leger (KNIL) en het leger in West-Indië (1815-1949). Den Haag: Nationaal Archief, 2004.

Block, Rainer. "Determinanten der preußischen Alphabetisierung im 19. Jahrhundert." Historical Social Research 21:1 (1996): 94-121.

Boogman, Johan Christiaan. Nederland en de Duitse Bond 1815-1851, (Diss. Utrecht.). Groningen-Djakarta: J. B. Wolters, 1955.

Bosma, Ulbe. Emigration: Colonial Circuits between Europe and Asia in the $19^{\text {th }}$ and Early $20^{\text {th }}$ Century." European History Online (EGO), published by the Institute of European History (IEG), Main 2011-05-02. http://www.ieg-ego.eu/bosmau-2011-en URN: urn:nbn: de:0159-20110201137, retrieved 12.12.2014.

—. "European Colonial Soldiers in the Nineteenth Century: Their Role in White Global Migration and Patterns of Colonial Settlement." Journal of Global History 4 (2009): 317-336.

- Indiëgangers. Verhalen van Nederlanders die naar Indië trokke-n. Amsterdam: Bert Bakker, 2010.

—. "Sailing through Suez from the South: The Emergence of an Indies-Dutch Migration Circuit, 1815-1940." International Migration Review 41:2 (2007): 511-536.

Bosma, Ulbe and Kees Mandemakers. "Indiëgangers: sociale herkomst en migratiemotieven (1830-1950). Een onderzoek op basis van de Historische Steekproef Nederlandse bevolking (HSN)." Bijdragen en mededelingen betreffende de geschiedenis der Nederlanden 123:2 (2008): 162-184.

Bosma, Ulbe and Remco Raben. Being "Dutch" in the Indies: A History of Creolisation and Empire, 1500-1920. Athens: Ohio University Press \& Swallow Press, 2008.

Bossenbroek, M. P. Volk voor Indië-De werving van Europese militairen voor de Nederlandse koloniale dienst, 1814-1909. Amsterdam: Van Soersen, 1992.

Bossenbroek, Martin. “'Dickköpfe und Leichtfüße': Deutsche im niederländischen Kolonialdienst des 19. Jahrhunderts." In Deutsche im Ausland - Fremde in Deutschland. Migration in Geschichte und Gegenwart, edited by Klaus J. Bade, 249-254. München: C. H. Beck, 1992. 
Brama, Door Liesbeth. De Koloniale Eeuw van Nederland-Collectie-inventaris NederlandsIndië 1816-1941. Den Haag: Nederlands Instituut voor Militaire Historie, 2005.

Buettner, Elizabeth. Empire Families: Britons and Late Imperial India. Oxford: Oxford University Press, 2004.

Calmes, Albert. Naissance et débuts du Grand-Duché (1814-1830). Histoire Contemporaine du Grand-Duché de Luxembourg, vol. 1. Luxembourg: Saint-Paul, 1971.

Calmes, Christian and Danielle Bossaert. Geschichte des Großherzogtums Luxemburg. Luxemburg: Saint-Paul, 1996.

Charney, Michael W. Southeast Asian Warfare 1300-1900. Leiden: Brill, 2004.

Chrisnach, P[ierre / Peter]. Geschichte der bewaffneten Macht des Luxemburger Landes, von den frühesten Zeiten bis zur Organisation der "Freiwilligen=Kompagnie." Grevenmacher: Obermosel = Zeitung, Eßlensche Druckerei, 1912.

Cookson, J. E. "Early Nineteenth-Century Scottish Military Pensioners as Homecoming Soldiers." The Historical Journal 52:2 (2009): 319-341.

Curtin, Philip D. Death by Migration: Europe's Encounter with the Tropical World in the Nineteenth Century. Cambridge: Cambridge University Press, 1989.

De Moor, Jaap A. "The Recruitment of Indonesian Soldiers for the Dutch Colonial Army, c. 1700-1950." In Guardians of Empire - The Armed Forces of the Colonial Powers c. 1700-1964, edited by David Killingray and David Omissi, 53-69. Manchester: Manchester University Press, 1999.

"Warmakers in the Archipelago: Dutch Expeditions in Nineteenth Century Indonesia." In Imperialism and War: Essays on Colonial Wars in Asia and Africa, edited by Jaap De Moor and H. L. Wesseling, 50-71. Leiden: E.J. Brill, 1989.

Dominy, G. "The Making of the Rough and the Respectable: The Imperial Garrison and the Wider Society in Colonial Natal." South African Historical Journal 37 (1997): 48-65.

Eckert, Heinrich A. and Dietrich Monten. Das deutsche Bundesheer-Nach dem Uniformwerk aus den Jahren 1835-1843, 1835. Reprint. Dortmund: Harenberg, 1990.

Erbe, Michael. Belgien, Niederlande, Luxembourg_Geschichte des niederländischen Raumes. Stuttgart: Kohlhammer, 1993.

Franz, Norbert. "Assistance municipale des pauvres de la ville de Luxembourg dans la deuxième moitié du XIXe siècle: le Bureau de Bienfaisance luxembourgeois (18501880)." In Luxembourg Paris Luxembourg. Migrations au temps de la Commune. Études d'histoire économique et sociale accompagnant l'exposition, edited by Henri Wehenkel, 33-42. Publications scientifiques du Musée d'Histoire de la Ville de Luxembourg. Luxembourg: Musée d'Histoire de la Ville de Luxembourg, 2001.

—. Die Stadtgemeinde Luxemburg im Spannungsfeld politischer und wirtschaftlicher Umwälzungen (1760-1890). Von der Festungs- und Garnisonsstadt zur offenen multifunktionalen Stadt. Trierer Historische Forschungen, Bd. 40. Trier: Kliomedia, 2001.

Geser, Hans. "Ausgangspunkte zu einer Soziologie kleiner Staaten: Drei systemtheoretische Perspektiven." In Kleinstaat: Grundsätzliche und aktuelle Problem, edited by Arno Waschkuhn, 37-70. Liechtenstein Politische Schriften, Bd. 16. Vaduz: Verlag der Liechtensteinischen Akademischen Gesellschaft, 1993.

Gilles, Philippe. Histoire des crises et des cycles économiques: Des crises industrielles du $19 e$ siècle aux crises financières actuelles. Paris: Armand Colin, 2009.

Gonner, Nicholas, ed. Luxembourgers in the New World, vol. 1. Esch-sur-Alzette: Schortgen, 1987.

Hack, Karl and Tobias Rettig, eds. Colonial Armies in Southeast Asia. London: Routledge, 2006.

Hacker, Peter. Die Anfänge eines eigenen Nationalbewußtseines?_Eine politische Geschichte Luxemburgs von 1815 bis 1865. Trier: Kliomedia, 2005. 
Hatz, Änder (André). Emigrants et Remigrants luxembourgeois de 1876 à 1900 (Etats-Unis d'Amérique, Argentine et pays extra-européens), Inventaire détaillé des "Mouvements de la population» par cantons, communes et localités, index de personnes et de lieux. Luxembourg: Archives Nationales Luxembourg, 1994.

Hausberger, Bernd. Globale Lebensläufe. Menschen als Akteure im weltgeschichtlichen Geschehen. Wien: Mandelbaum, 2006.

Hellinghausen, Georges. "Luxemburger in den päpstlichen Armeen.” Nos cahiers-Lëtzeburger Zäitschrëft fir Kultur 27:2 (2006): 69-111.

Hippler, Thomas. "The French Army, 1789-1914: Volunteers, Pressed Soldiers, and Conscripts." In Fighting for a Living: A Comparative History of Military Labour 1500-2000, edited by Erik-Jan Zürcher, 419-446. Amsterdam: Amsterdam University Press, 2013.

Ispert, Wolfgang. ed. Deutsche aus Luxemburg bei der Niederländisch-Ostindischen Kolonialarmee von 1780 bis 1895, Veröffentlichung Nr. 11 der Forschungsstelle "Volk und Raum." Soest: Der Meilenstein Verlag, 1944.

Jung, Math[ias]. "Vom Jägerbataillon zur Freiwilligenkompagnie-Eine Seite heimatlicher Militärgeschichte (...)." De Lëtzeburger Ex-Militär-Organ des Luxemburger Ex-Militärverbandes 4:3 (1936): 38-48.

Kägi, Kaspar and Konrad J Kuhn. "Kolonialexpansion, fremde Dienste und SklavereiJakob Christoph Zieglers (1791-1825) Briefe aus Sumatra.” Zürcher Taschenbuch 130 (2010): 71-141.

Kalifa, Dominique. Biribi: les bagnes coloniaux de l'armée française. Paris: Perrin, 2009.

Kayser, Simone. La lutte contre la pauvreté au Grand-Duché de Luxembourg 1839-1880. Unpublished typescript. Luxembourg: Bibliothèque Nationale du Grand-Duché de Luxembourg, 1996.

Koller, Christian. Die Fremdenlegion: Kolonialismus, Söldnertum, Gewalt, 1831-1962. Paderborn: Ferdinand Schöningh, 2013.

Koller, Christian and Peter Huber. "Armut, Arbeit, Abenteuer-Sozialprofil und Motivationsstruktur von Schweizer Söldnern in der Moderne." Vierteljahrschrift für Sozial- und Wirtschaftsgeschichte 102:1 (2015): 30-51.

Kolnberger, Thomas. ed. August Kohl_ein Luxemburger Söldner im Indonesien des 19. Jahrhunderts. Mersch (Luxembourg): Centre National de Littérature, 2015.

Laslett, Peter. "Characteristics of the Western Family Considered over Time." Journal of Family History 2:2 (1977): 89-115.

Lester, Alan. Imperial Networks: Creating Identities in Nineteenth-Century South Africa and Britain. London: Routledge, 2001.

Liez, N[icolas / Nikolaus]. Major Franz Karl Hartmann -Letzter Commandeur des Kgl. Großh. Luxemburgischen I. Jägerbataillons zum deutschen Bundesheere. Lebensereignisse eines Luxemburgers, edited by N. Liez. Luxemburg: Peter Brück, 1889.

"Het Luxemburgsche bonds-contingent." Militaire Spectator 30/1861, 694-98.

Marraro, Howard. "Canadian and American Zouaves in the Papal Army, 1868-1870." Canadian Catholic Historical Association Report 12 (1944-45): 83-102.

Marshall, P. J. "British Immigration in to India in the Nineteenth Century." In European Expansion and Migration: Essays on the Intercontinental Migration from Africa, Asia and Europe, edited by P. C. Emmer and M. Mörner, 179-196. New York: Berg, 1992.

Meyer, Philipp Anton Guido von. Staats=Acten für Geschichte und öffentliches Recht des Deutschen Bundes. Corpus Juris Confoederationis Germanicae. (Zweite Auflage). Nach officiellen Quellen. Frankfurt am Main: In Commission bei Ferdinand Boselli, 1832.

Michels, Stefanie. Schwarze deutsche Kolonialsoldaten. Mehrdeutige Repräsentationsräume und früher Kosmopolitismus in Afrika. Bielefeld: Transcript, 2009. 
Moes, Règis. Cette colonie qui nous appartient un peu. La communauté luxembourgeoise au Congo belge 1883-1960. Luxembourg: Fondation Robert-Krieps-Editions d'Lëtzebuerger Land, 2012.

Moreno Fraginals, Manuel R. and Moreno Masó. Guerra, Migración y Muerte (El ejército español en Cuba como via migratoria). Colombres: Fundacíon Archivo Indianos, 1993.

Müller, Jürgen. Der Deutsche Bund 1815-1866. Enzyklopädie Deutscher Geschichte, vol. 78. München: Oldenburg, 2006.

Osterhammel, Jürgen. Colonialism: A Theoretical Overview, $2^{\text {nd }}$ ed. Princeton: Markus Wiener Pub, 2005.

Pauly, Michel. "L'immigration dans la longue durée. Esquisse introductive." In Lëtzeburg de Lëtzebuerger - La Luxembourg face à l'immigration, edited by Michel Pauly, 7-22. Luxembourg: Editions Guy Binsfeld, [1985].

—. Geschichte Luxemburgs. München: C. H. Beck, 2011.

Péporté, Pit, Kmec, Sonja et al. Inventing Luxembourg - Representations of the Past, Space and Language from the Nineteenth to the Twenty-First Century. Leiden: Brill, 2010.

Saalfeld, Friedrich. Allgemeine Kolonialgeschichte des neueren Europas Abtheilung 1, Bd. 2. Göttingen: Dieterich, 1812.

Scuto, Denis. "Les Luxembourgeois à Paris." In Itinéraires croisés. Luxembourgeois à l'étranger, étrangers au Luxembourg (Menschen in Bewegung. Luxemburger im Ausland, Fremde in Luxemburg), edited by Antoinette Reuter and Denis Scuto, 144-147. Esch-surAlzette: Editions Le Phare, 1995.

. "Staatsbildung und Staatsangehörigkeitsrecht in Luxemburg: zwischen Inklusion und Exklusion (1804-1940)." In Nationenbildung und Demokratie-Europäische Entwicklungen gesellschaftlicher Partizipation, edited by Norbert Franz and Jean-Paul Lehners, 249-280. Luxemburg-Studien / Études luxembourgeoises vol. 2. Frankfurt/Main: Peter Lang, 2013.

Seger, Otto. Unsere Vorfahren als Söldner in fremden Diensten. N.p.: Historischer Verein für das Fürstentum Liechtenstein, 1979.

Spiers, Edward M. The Army and Society 1815-1914. London: Longman, 1980.

—. "Army Organization and Society in the Nineteenth Century." In A Military History of Ireland, edited by Thomas Bartlett and Keith Jeffery, 335-357. Cambridge: Cambridge University Press, 1996.

STATEC (Luxembourg). Population totale, luxembourgeoise et étrangère, de résidence habituelle au Luxembourg selon le sexe 1821-2013, http://www.statistiques.public.lu. Accessed Dec. 12, 2014.

—. Statistiques historiques 1839-1898, Service Central de la Statistique et des Etudes Economiques, Grand-Duché de Luxembourg, 1990. http://www.statistiques.public.lu. Accessed Dec. 12, 2014.

Staus, Yvan. "The Luxembourgers in the Dutch East-Indian Army from 1810 to 1913-A Case Study of Colonial Population Movements to South East Asia in the $19^{\text {th }}$ Century." Hémecht-Zeitschrift für Luxemburger Geschichte / Revue d'histoire luxembourgeoise 61:4 (2009): 467-493.

Teitler, Gerke. "The Mixed Company: Fighting Power and Ethnic Relations in the Dutch Colonial Army, 1890-1920." In Colonial Armies in Southeast Asia, edited by Karl Hack and Tobias Rettig, 154-168. London: Routledge, 2006.

Trausch, Gilbert. "Comment faire d'un état de convention une nation." In Histoire du Luxembourg. Le destin européen d'un "petit pays," edited by Gilbert Trausch, 201-74. Toulouse: Éditions Privat, 2003.

Troes, Johann Peter. "Die Luxemburger in der niederländisch-indischen Kolonialarmee von 1825 in 1913." Ons Hémecht 1, 5-11 (1913); 2, 5, 7-11 (1914); 3, 4, 7, 8, 11, 12 (1915); 1-9 
(1916); 4, 5, 7, 10-12 (1917); 9, 10 (1923) [without pages]. Since volume 63:3 (2011) Hémecht-Revue d'histoire luxembourgeoise-Zeitschrift für Luxemburger Geschichte.

Van Gelder, Roelof. Het Oost-indisch avontuur. Duitsers in dienst van der VOC (1600-1800). Nijmwegen: SUN, 1997.

Volkstelling 1930. Europeanen in Nederlandsch-Indië. Vol. 6, Census of 1930 in the Netherlands Indies. Batavia: Landsdrukkerij, 1933.

Voss, Peter. "Der bürokratische Wendepunkt von 1843: Die Primärschule im Prozess der Luxemburger Nationalstaatsbildung des 19. Jahrhunderts." In Verwaltete SchuleGeschichte und Gegenwart, edited by Michael Geiss and Andrea De Vincenti, 53-70. Wiesbaden: Springer, 2012.

Wahl, Ferdinand. "La Fortune aux Indes! Souvenirs d'un volontaire à l'armée des Indes (18761886)." Hémecht-Zeitschrift für Luxemburger Geschichte / Revue d'histoire luxembourgeoise 51:1 (1999): 79-107.

Way, Peter. "The Scum of Every Country, the Refuse of Mankind." In Fighting for a Living: A Comparative History of Military Labour 1500-2000, edited by Erik-Jan Zürcher, 292-329. Amsterdam: Amsterdam University Press, 2013.

Wey, Claude. "Luxemburg und die luso-brasilianische Welt. Ein typologischer Ansatz zu den Beziehungen Luxemburgs mit Portugal und Brasilien vom 16. Jahrhundert bis 1970." In Aufbrüche und Vermittlungen-Beiträge zur Luxemburger und europäischen Literatur- und Kulturgeschichte (Nouveaux horizons et médiations-Contriburtions à l'histoire littéraire et culturelle au Luxembourg et en Europe), edited by Claude D. Conter and Nicole Sahl, 269-290. Bielefeld: Aisthesis Verlag, 2010.

Woollacott, Angela, Desley Deacon and Penny Russell. eds. Transnational Lives: Biographies of Global Modernity, 1700-Present. New York: Palgrave Macmillan, 2010.

Zangger, Andreas. Koloniale Schweiz-Ein Stück Globalgeschichte zwischen Europa und Südostasien (1860-1930). Bielefeld: Transcript Verlag, 2011.

Zelle, L[ouis].J[oseph] (Capitän a. D. der ostindischen Armee). Einiges über Niederländisch = Ostindien (Abdruck aus der "Lux. Ztg."). Luxemburg: Th. SchöllLuxemburg, 1889.

Zirkel, Kirstin. "Military Power in German Colonial Policy: The Schutztruppen and Their Leaders in East and South-West Africa, 1888-1918." In Guardians of Empire-The Armed Forces of the Colonial Powers c. 1700-1964, edited by David Killingray and David Omissi, 91-113. Manchester: Manchester University Press, 1999.

Zürcher, Erik-Jan. "Introduction: Understanding Changes in Military Recruitment and Employment Worldwide." In Fighting for a Living: A Comparative History of Military Labour 1500-2000, edited by Erik-Jan Zürcher, 11-42. Amsterdam: Amsterdam University Press, 2013.

\section{Notes}

* Ulbe Bosma is Senior Researcher at the International Institute of Social History in Amsterdam and Professor of International Comparative Social History at the Vrije Universiteit Amsterdam. His fields of interest are global commodity production and colonial migrations. Among his publications on this topic are "Sailing through Suez from the South" (International Migration Review) and "European
Colonial Soldiers in the Nineteenth Century" (Journal of Global History).

Thomas Kolnberger, is a postdoc researcher specialising in military history, urban history, and historical geography. The primary research for this article was undertaken for the critical edition of the memoires of a Luxembourgish soldier of the KNIL, 2014-15. Currently he is project coordinator of 
www.transmortality.uni.lu at the University of Luxembourg. The authors wish to express their thanks to the anonymous referees for their suggestions to improve the article.

1 Bayly, "Archaic' and 'Modern' Globalization"; Buettner, Empire Families; Hausberger, Globale Lebensläufe; Lester, Imperial Networks; and Woollacott, et al., Transnational Lives.

2 Bosma, "European Colonial Soldiers," 324.

3 Osterhammel, "Colonialism," 60.

4 Curtin, Death by migration, 1.

5 Arnold, "White Colonization"; Marshall, "British Immigration"; Moreno Fraginals and Masó, "Guerra," 101, 136; and Dominy "The Making of the Rough."

6 An overview on Swiss mercenaries of the nineteenth century is not available; the research is concentrating on the early modern period in Europe: information derived from personal conversation with Prof. Koller. Compare: http://www.hlsdhs-dss.ch/textes/d/D8608.php, retrieved 9 June 2016. For Luxembourg, Régis Moes portrays in a similarly critical way "a piece of Luxembourg abroad." See Moes, Cette colonie.

7 Spiers, The Army and Society, 50.

8 Spiers, "Army organization," 335-37.

9 See Marshall, "British Immigration in to India in the Nineteenth Century."

10 Spiers, The Army and Society, 46.

11 Kalifa, Biribi; compare Hippler, "The French Army," 433 and 446, and Koller, Die Fremdenlegion. According to Kalifa, between 600,000 and 800,000 men from 1818 to the 1960s; Kalifa, Biribi, 314.

12 In this respect, the German colonial troops (Schutztruppen) were never part of the Reichsheer but were assigned to the Foreign Office at first, then the Navy Ministry (Reichsmarineamt), and finally to the Colonial Office. They numbered only a few thousand, and little is known about their social background. Zirkel, "Military Power," 110f.; compare Michels, Schwarze deutsche Kolonialsoldaten.
13 Bossenbroek, Volk voor Indië; and Bosma, Indiëgangers.

14 Cookson, "Nineteenth-Century Scottish," 320.

15 In Luxembourg, the "emigration law" ("Gesetz vom 13. März 1870, das Auswandern betreffend," Memorial des Groß-Herzogthums Nr. 4, 25 March 1870) specified the role of these licenced emigration agents, who were entitled to recruit Luxembourgers for foreign army services. From 1870 until 1900, the grand duchy's government certified twentyeight individual agents for this purpose.

16 STATEC, Population.

17 Bosma, Indiëgangers, 154.

18 Saalfeld, Allgemeine Kolonialgeschichte, 243. Most of these mercenaries were Walloons, had French names, and came from the francophone part of the Austrian Netherlands (Belgium Austriacum).

19 Zürcher, "Introduction."

20 For the Swiss professional soldiers in the Dutch army, see Amersfoort, Koning en kanton. Recently, Andreas Zangger investigated the role of Swiss civilians who immigrated to Southeast Asian colonies; Zangger, Koloniale Schweiz, for Swiss mercenaries: Koller and Huber, "Armut, Arbeit, Abenteuer."

21 Norbert Franz draws the poverty line - a factual "breadline"-for a four-person family in Luxembourg City in the 1850s at an annual income of at least 400 francs (the equivalent of 200 Dutch guilders). This income group defines the Unterschichten (underclass), representing 28 percent of the total town population (61 percent are middle- and 11 percent upper-class). See Franz, Die Stadtgemeinde Luxemburg, 254.

22 Bosma, "Sailing through Suez from the South."

23 After the Belgian Revolution, Limburg (Hertogdom Limburg) played a similar dual role as member state of the German Confederation and province of the Kingdom of the Netherlands at the same time (1839-66); Boogman, Nederland en de Duitse Bond. When the Confederation 
was dissolved, Limburg - as a province of the Netherlands - had to leave the German Customs Union, of which Luxembourg - as an independent and henceforth neutral country - remained a member.

24 Luxembourg's contingent to the Bundesheer - each member had to fulfil a quota according to the size of the country - amounted to a total of 3,000 under Dutch command. This number, like the shares of the other member states - a total of approximately 300,000 men in 1835 - are theoretical figures. See Eckert and Monten, Das deutsche Bundesheer. At the end of the German Confederacy, the Grand Duchy levied 1,582 soldiers (including eight civilians); see Verordnungs $=$ und Verwaltungsblatt des Großherzogthums Luxemburg No. 31, September 1863.

25 William I ceded the right to man and command the fortress to the Prussian king in 1816. Initially, the garrison's ratio of Prussian soldiers to Luxemburgish militiamen was 4:1. Between 1856 and 1866/67, the garrison consisted of Prussian military staff only; see Calmes, Naissance et débuts du Grand-Duché, and Trausch, "Comment faire d'un état de convention une nation," 209-10, as well as Angelow, Von Wien nach Königgrätz, and Müller, Der Deutsche Bund.

26 Voluminous files at the National Archives of Luxembourg (ANLux L-045-089, Secrétariat de La Haye) document the official correspondence between Luxembourg and the court in The Hague from 1839 until 1890. Many cases deal with military matters, especially pensions (also for colonial soldiers of His Majesty) and exemption from military service in Luxembourg.

27 In 1912, Nassau-Weilburg became Luxembourg-Nassau for national-patriotic reasons, similar to those of the British royal house of Saxe-Coburg and Gotha, which changed its name to Windsor in 1917.

28 Hacker, Die Anfänge eines eigenen Nationalbewußtseins?; and Péporté, Pit et al., Inventing Luxembourg.
29 A second exception was the Principality of Liechtenstein, which was part of the German Confederation but had a customs and monetary union with Austria. Like Luxembourg, Liechtenstein was a "mercenary exporting country" that also supplied the Dutch colonial military. See Seger, Unsere Vorfahren als Söldner in fremden Diensten.

30 This number results from the crosscheck of Dutch and Luxembourgish sources by Thomas Kolnberger. The statistic goes back to the 1780s; see Staus "The Luxembourgers in the Dutch EastIndian Army." Staus lists all Luxembourgers who-according to Hatz, Emigrants et Remigrants-left for the Dutch East Indies and declared their enlistment in the colonial army overseas, according to Troes (1913-17). Kolnberger crosschecked these figures with Wolfgang Ispert's data (Ispert, Deutsche aus Luxemburg), which were probably based upon the enrolment lists of the colonial army, and checked these data with the "Stamboeken" of the NA and CBG in The Hague. In addition, the authors have consulted further primary sources of the ANLux in Luxembourg. See Kolnberger, August Kohl.

31 Obviously, Germans might have enlisted as Luxembourgers. So far, we only know of some diplomatic intervention from the German-Prussian side to close this option for "deserters" to flee to America in 1857. In 1888, a people-smuggling ring based in Brussels was exposed. They used false Luxembourgish identity papers to bring Germans (emigrants or deserters) out of the country as KNIL recruits. This grey labour and black market for trafficking is a desideratum for further research. See Staus, "The Luxembourgers in the Dutch East-Indian Army," 487.

32 Bossenbroek calculates an average colonial "Detachements" (replacements) with 1,836 soldiers; see Bossenbroek, Volk voor Indië, 85, 133, 277.

33 Ibid., 184.

34 See footnote 4 above. 
35 See the ten biographical sketches below.

36 Volkstelling 1930, vol. 6, 275.

37 Troes, Ons Hémecht 2 (1913): 61 (II.Teil/2. Böferding). See ibid. 5 (1913): 244 (153. Hennico) for more on this soldier who enlisted in Belgian, Dutch, Luxemburgish, and German Federation army during his lifetime.

38 Bossenbroek, "Dickköpfe und Leichtfüße'," 251.

39 Bosma, Indiëgangers, 157.

40 Bossenbroek, "Dickköpfe und Leichtfüße'," 251.

41 Jean Baptiste Cleerens (1785-1850, later adjutant of the General Governor of the East Indies and Governor of the Moluccas) formed the "Jagers van Cleerens" in 1831 during the Belgian Revolution. It was moved to Java and became the $9^{\text {th }}$ Infantry Battalion of the KNIL.

42 Volunteer force of light infantry formed in defence of the Papal States against Garibaldi's troops during the last wars of Italian unification (1866-70). Originally a unit of the Franco-Belgian Tirailleurs (1860), the Zouaves developed into a multinational fighting force until the capture of Rome 1870. The papal troops also comprised Dutch (with 1,910 riflemen the second-largest group after French volunteers) and Belgians (686). The two Luxembourgers might have been subsumed in these figures provided by Marraro "Canadian and American Zouaves." See Hellinghausen, "Luxemburger in den päpstlichen Armeen."

43 From 1854-56, the British recruited foreign mercenary troops for the Crimean War (1853-56); see Bayley, Mercenaries for the Crimea.

44 Calmes, Naissance et débuts du GrandDuché; [anon.], "Het Luxemburgsche bonds-contingent"; compare footnote 16.

45 Verordnungs = und Verwaltungsblatt des Großherzogthums Luxemburg No. 7, 21 January 1841, with additions: No.12 and No. 15 of the same year.

46 Meyer, Staats-Acten, 375ff. (Allgemeine Cartell $=$ Convention unter den deutschen
Bundesstaaten, vom 10. Februar 1831 und vom 17. Mai 1832.); Kolnberger, August Kohl, 198.

47 Franz, Die Stadtgemeinde Luxemburg, $184 \mathrm{ff}$.

48 Staus, "The Luxembourgers in the Dutch East-Indian Army," 476.

49 Ibid., 489.

50 Bosma, Indiëgangers, 172; and Gilles, Histoire des crises.

51 Cookson, "Nineteenth-Century Scottish," 341.

52 Bosma, "Sailing through Suez from the South," 518.

53 The mortality rate in the European military in the Dutch East Indies declined substantially from the 1840s onwards, and the Luxembourg soldiers are no exception to the rule. See Staus, "The Luxembourgers in the Dutch East-Indian Army," 481ff., and Bosma, "Sailing through Suez from the South," 518-20.

54 See Bosma and Mandemakers, "Indiëgangers."

55 STATEC, Statistiques historiques 1839 1898, chapter: Enseignement et Culture (515ff.).

56 Voss "Der bürokratische Wendepunkt," 67; and Block "Determinanten," 117.

57 Way, "The Scum of Every Country'," 291; with respect to the Netherlands, compare Amersfoort, "The Dutch Army," 471.

58 For the "connectivity model" theses of small states theory, see Geser, "Ausgangspunkte"; Wolf, "Die Erforschung"; and Péporte, Kmec, et al., Inventing Luxembourg.

59 Troes, "Die Luxemburger." Compare Kolnberger, "August Kohl” and Zürcher "Introduction."

60 Kolnberger, "August Kohl," 215.

61 Troes, Ons Hémecht 3-4 (1915), 73-74 (No. 442).

62 Pauly, Geschichte, 78-82, and Pauly, "L'immigration," 11-13; and Abbaye de Neumünster, Präsenz.

63 "Proto-welfare State" for "Sozialstaat" would be more appropriate because the full welfare state of Luxembourg would only arrive after the Second World War. 
64 Kayser La lutte, 22-23, 88-91, 106-109, 139-41; and Franz "Assistance," 33-42.

65 Scuto, "Les Luxembourgeois."

66 Bosma, Indiëgangers, 168.

67 Adjutant-Unteroffizier is the highest rank possible for a soldier without Dutch citizenship.

68 Only fifty-seven signed a second military contract, and six a third. These contracts were consecutive, that is, without leaving Asia for Europe. The average service time for Luxembourgers was seven years.

69 Troes, Ons Hémecht 1915, 11/12, 271 (number 692).

70 After a longer period, Franz-Michael Schneider from Ettelbrück (number 881 on the list of Troes's account) was promoted to officer of the KNIL: "That issince 1869- the first Luxembourger, who earned the epaulettes of an officer," commented Martin Blum from the ObermoselZeitung, see Troes, Ons Hémecht 1916, 8 u. 9, 285; Ludwig-Joseph Zelle served 1854 80 in the Indies, became officer with a "field promotion" in 1867; see Zelle, Einiges über Niederländisch $=$ Ostindien. $\quad$ Franz-Karl Hartmann (served 1829-41) became a major and last commanding officer of the 1st Battalion of the Luxembourgish "Bundescontingent." Troes, Ons Hémecht 1917, 7, 218f. Compare Liez, Major Franz Karl Hartmann.

71 Troes, Ons Hémecht 1913, 8/9, 409. "Heinrich Knoerl served the Prussian
Army as First Lieutenant (Oberleutnant) before he joined the Army of the Netherlands where he rose in rank to the position of adjutant (aide-de-camps) of the Governor-General Johannes van der Bosch in 1830;" Troes, Ons Hémecht 1931, 2, 62.

72 Bosma, "Sailing through Suez from the South," 523.

73 The overall rate of (potential) Luxembourgish residents in the Dutch East Indies from the 1850 s to the 1910 s is around 15 percent.

74 Laslett, "Characteristics of the Western family." In a nutshell, the original concept defines an intermediate phase in the life of domestic servants before marriage, facilitating the accumulation of savings for the establishment of a new household.

75 Bosma, "Sailing through Suez from the South," 515.

76 Staus, "The Luxembourgers in the Dutch East-Indian Army," 478.

77 Gonner, Luxembourgers in the New World.

78 Wey, "Luxemburg und die lusobrasilianische Welt."

79 Troes, Ons Hémecht 1913, 6, 282-87 (number 160), compare: http://www. autorenlexikon.lu/page/author/208/2085/ DEU/index.html, accessed June 9, 2015.

80 Troes, Ons Hémecht 1916, 6, 189 (number 861). 


\section{Appendix 1: Archival and Printed Sources of Luxembourgers in the Dutch Colonial Army.}

ANLux $=$ National Archive, Luxembourg (Archives nationales de Luxembourg, Grand-Duché de Luxembourg):

AE-02266 Luxembourgeois engagés dans l'armée des Indes néerlandaises (1880-1912)

AE-02276 Luxembourgeois engagés dans l'armée des Indes néerlandaises (1920-1923)

G-0908 Pensionnaires belges-exécution du traité du 5 novembre 1842-Pensionnaires néerlandais - Légionnaires

G-0069 Service militaire à l'étranger (1846-1856)

H-0058 Service militaire étranger-Libération, renseignements, legs Napoléon $1^{\text {er }}$

H-0786 Autorisations de rentrer dans le Grand-Duché

G-0949 Mouvement de la Population (1841-1900)

$\mathrm{CBG}=$ Centraal Bureau voor Genealogie, Den Haag:

Stamboeken Militairen KNIL (Koninklijk Nederlandsch-Indisch Leger): Inv.-Nr. 38-42, 86, 323 (1857-1865), 324 (1866-1875), 321 (1834-1844), 44- 447 (1832-1939), 510-12 (ab 1890/91 bis 1909[?])

NA = National Archives, The Hague (Nationaal Archief, Den Haag):

Inventory number/Toegang 2.10.50, inventarisnrs. 87-331 (Suppletiefolio) Ministerie van Koloniën: Stamboeken en pensioenregisters Militairen Oost-Indië en West-Indië 